\title{
Power, paternalism and children on the move
}

Kyle Vella

\begin{abstract}
Background: In this article I set out to critically explore how campaigning for the rights of "children on the move" impacts on paternalism in humanitarianism. My aim was to trace the development of the notion of children on the move, the productive power that permeates it, and the way this translates into paternalism in humanitarianism.

Methods: I applied Foucauldian discourse analysis to textual data gathered from relevant publications. I mainly collected these texts from the Destination Unknown campaign, coordinated by Terre des Hommes, which serves as the case study for this research. In addition, I conducted and interview with a key Destination Unknown official in order to gather insights on the actual running of the campaign. I analysed the data through an existing conceptual framework informed by a Foucauldian perspective on power and paternalism, where the presence of power in humanitarianism is explained through the notion of paternalism.

Results: Using this method, I describe the two main features of power within the field of children on the move: the power to shape reality through the construction of a relatively new concept and the power of moral and expert authority.

Conclusions: In this article I show that these features of power can be explained in humanitarianism through the notion of paternalism, as exhibited by the various acts of imposition in the (supposed) best interests of the child. This research is a critique, rather than a criticism, of the efforts to promote the rights of children on the move, and shows how paternalism is an inherent ingredient of humanitarianism.
\end{abstract}

Keywords: Power, Paternalism, Children on the move, Human rights, Foucauldian discourse analysis

One should not fail to notice the almost benevolent nuances present in all the words with which the Greek nobility distinguishes the lower people from itself; how a kind of pity, consideration, and forbearance continually intervenes and sweetens, until ultimately almost all the words applied to the common man survive as expressions meaning "unhappy", "pitiable".

Friedrich Nietzsche, from On the Genealogy of Morals (Nietzsche \& Smith 2008)

\section{Introduction}

Out of more than 950 million international or internal migrants worldwide, one third are youths, between 12 and 25 years of age, with many of these being under the age of 18; this, according to international law, means that they are defined as "children" (Global Movement for Children 2010). This paper was written at a time when child migration was progressively becoming a central issue in youth studies, as demonstrated by the choice of the topic of "Youth and Migration" at the last United Nations World Youth Report (Unworldyouthreport.org 2013). The momentum built by these developments makes a critical analysis of the field not just relevant but also necessary.

The term "children on the move"1 has emerged in recent years in the discourse of child migration, capturing within its wide confines a number of previously unrelated "categories" of children. While individual categories, like trafficked children and unaccompanied migrants, have been 
addressed by countless campaigns, activities and organisations, they have never been looked at as a single target group. A newly constructed field is surfacing, and the nature of which has never been critically analysed; my purpose in this research, therefore, is to explore the impact that campaigning for the rights of children on the move (COTM) has on the discourse of humanitarian action.

I take the Destination Unknown campaign (DU) led by the Terre des Hommes International Federation (TDHIF) as a case study. The DU is designed as an international campaign to protect COTM and is supported by partners who have joined forces to develop protection mechanisms for COTM, raise awareness and advocate the campaign's message for policy change.

This research employs a qualitative approach, in the form of Foucauldian discourse analysis (FDA), to achieve its aims, these being to:

- Trace the development of the concept of COTM and its definition

- Explore the manifestations of power expressed in campaigning for the rights of COTM

- Explore the impact this has on paternalism in humanitarian action

The texts used were mostly, but not exclusively, obtained from the DU website (Destination Unknown 2014), since the DU is the primary case study of this research. They were all published by TDHIF or its partners within, or with the spirit of the campaign, and can be freely downloaded from the website. A qualitative, semi-structured interview was also conducted with Salvatore Parata, the Head of the TDHIF European Office.

This paper starts with a brief discussion on how the concept of "childhood" is constructed across space and time and how this impacts on paternalism in the field of the rights of the child. The theoretical framework I use in this paper follows Barnett's (2010) conceptualisation of power, paternalism and humanitarianism, based on a taxonomy of power developed by him and Duvall (2005). It relies on productive power, which mirrors the characteristics of Foucauldian disciplinary power, and is best described in humanitarianism through the notion of paternalism.

The ensuing analysis is divided into three parts. The first part contextualises the term COTM and its development into an internationally recognised concept. Secondly, the notion of authority in campaigning for the rights of COTM, and the way this authority echoes productive power in the field, is explored. Finally, the third part brings to focus all the elements of productive power in the DU by capturing it within the parameters of paternalism in humanitarianism.

The critical analysis of the DU reveals embedded paternalistic features that not only concern the organisation, strategy and implementation of the campaign but also are deeply rooted in a much broader international humanitarian project. Although the concept of paternalism is not new to humanitarianism, the critical conceptual framework employed here has never been used in academic literature to analyse the field of the rights of COTM.

\section{Background \\ Childhood-a socially and historically constructed concept}

Humanitarianism, like paternalism, is inspired by an ethics of care and seeks a certain amount of control over the lives of others (Barnett 2011). A basic illustration of paternalism is the traditional example of the father caring about and trying to control the child's life and decisions. In the same way, according to Barnett, the humanitarian actor interferes in the recipient's life, even if with the best of intentions and the utmost of care. This is the paradox of paternalism, which is at once constructive and destructive in its practical and moral implications. While "caring" in itself is an inherently good thing, when that caring verges on control, the negative face of humanitarianism is revealed.

Archard (2006) notes that, for some writers, one cannot capture the early years of an individual's life within a single precise notion. In this sense, the term childhood becomes disassociated from biology and ends up being a social construct in its entirety (what Cannella and Viruru refer to as the 'construction of the child' (Cannella and Viruru 2004, p. 63)). Fass (2013), for instance, aptly entitles the second part of her edited history of childhood, Creating Childhoods in the Western World while, in a separate case, Burman (2008) pointedly asks: which children? Archard also points out, however, that other authors find evidence of a specific and universal meaning to those early years in the various notions of childhood in every society and culture. That said, Archard (2006, p. 6)commits himself when he says that there is a particularly modern and arguably Western view of the child as a vulnerable, weak, and dependent creature, bereft of those capacities that entitle adults to be regarded as full members of our society' and therefore "citizens in waiting".

Finn and Nybell et al. describe the malleability of "childhood" by analysing the influence globalisation has on it. This dynamic also highlights the importance of children to their families in the processes of migration, pioneering integration within the family that is still adapting to its new surroundings (Finn et al. 2010, p. 248). Archard's identification of the Western notion of the child as 'a vulnerable, weak, and dependent creature' hardly coincides with the migrant child who is the first person within the family to confront its new surroundings and to adapt to 'changing meanings of identity and belonging' (Ibid.). This is a key point to make in light of the current research on COTM and their supposed vulnerabilities. 
The "modernity" of the "Western" notion of childhood implies a position along time as well as space, thus a historical construction of the idea. If one concedes that the notion of childhood is socially constructed, it follows that this construction changes along time as social circumstances change. Frijhoff (2012) describes the historical constructions and reconstructions of childhood as 'discoveries of childhood'. Throughout history, successive writers have tried to define childhood in different ways. What we know of children in history is mediated to us by adults, since children themselves rarely have a voice in the writing of history. Thus, 'no child has ever discovered itself as a child. The child is not self-reflexive in history; as a historical issue, it is a virtual theme of discovery by others' (Frijhoff 2012, p. 12).

There is a general consensus, among those who believe that childhood is a socially constructed notion ${ }^{2}$, that Philippe Ariès (1914-1984) was the first writer who historicised the child, or the attitude towards it. He claimed that modern Europeans invented the current notion of childhood and that pre-modern societies had no such concept. It is within this analysis of scholarly practice that childhood was first seen as an object of intervention and discipline ${ }^{3}$.

With this background, one can easily notice a crucial limitation in the practice of disseminating a universal idea of childhood. "Childhood" being socially and historically constructed suggests that the way society looks and reacts to children is different for societies that have had different trajectories in history, as well as different geographical circumstances. Understanding the dangers of the so-called cultural colonialism (Ebrahim 2012) is a vital step in appreciating how paternalism is part and parcel of the human rights project.

Khan argues that in actual fact, notions of childhood around the world are not uniform and are directly formed and influenced by history and geography (Khan 2010). This implies that there cannot be a universal definition of childhood and that imposing such a definition can have adverse impacts on the ground, such as those felt in the efforts against child labour in Pakistan ${ }^{4}$. If the notion of universal childhood is to be held true, then it logically follows that children who do not fit within the parameters set by such a universal definition of childhood no longer have an accepted "childhood" (Burman 2008, p. 10). Cordero Arce gives the example of street children, whom he dubs 'the ultimate outlaws'-outside society and outside of childhood (Cordero Arce 2012). Indeed, "it is not only children who are affected by these paternalist conventions [but also] the maturity, responsibility and autonomy associated with the classes, families, countries and even regions those children are associated with" (Burman 2008: 10).

Yet it appears that international law accepts that childhood as experienced in the West is "proper" and should be an example for the rest of the world. This Eurocentric approach to childhood is backed by years of Western knowledge, entrenched in science and society, which is therefore deemed to be superior (Ebrahim 2012, p. 80). Edward Said's notion of Orientalism is a broad area of exploration that can be opened here. For the purpose of this discussion, however, it will suffice to say that as the idea of the backward and primitive non-European legitimised imperial colonialism (Hamed Aladaylah 2012, p. 122), the perception of the Western concept of childhood as an example to follow legitimises cultural colonialism.

At a national level of analysis, the rights of the child usually compel the state to be pro-active rather than reactive in the child's life, and this creates tensions between economic (right to provision and right to protection) and political (right to autonomy) rights. This conflict reflects the complex paradox that child rights theorists face when trying to escape paternalism - by paternalistically securing economic rights, they are trampling on political rights. More importantly, it deepens the question: whose rights? Are we advocating for a right to protect (therefore of an authority to act and intervene in the life of a child) or the right for protection (the child as an autonomous being)?

The Western concept of childhood, where the child is protected as, and from, itself, has become globalised through various mechanisms. These mechanisms include, but are not restricted to, international institutions, media and international treaties such as The United $\mathrm{Na}$ tions Convention on the Rights of the Child (UNCRC). The UNCRC is based on the assumption of a 'global childhood' (Ebrahim 2012, p. 80) wherein the way adults deal with children in the Western world is privileged and declared as a basis for concomitant universal human rights. In his critique of the universal nature of childhood, Cordero Arce points out that, after all, the UNCRC is the Convention on the Rights of the Rights of The Child (Cordero Arce 2012).

Paternalism was found to be evident in the UNCRC by Gadda who argues that, through the UNCRC, the UN acts as a disciplinary force at an international level that surveils over nations and maintains order by producing knowledge. In this way, 'the CRC does not contest, but reinforces power relations; i.e., of adults over children, of Western over non-Western nations' (Gadda 2008, p. 10). This results in what Pupavac calls a 'misanthropy without borders' where 'the convention universalizes misanthropy and legitimizes an unequal international order' (Pupavac 2001). Reynolds et al. (2006) acknowledge that children's rights exist independently of the UNCRC and that the latter had the important role of grounding the child as an actor into the legal system. Yet they also point out how, for instance, when notions such as the child's best interest (explored below) are put into practice, they clash with the opinions of the children 
themselves. Moreover, the UNCRC provided an instrument for non-governmental organisations (NGOs) and international agencies to legitimately act upon.

Two key paternalistic relationships therefore emerge from the area of child rights. The first one-that between the adult and the child-is the easiest to defend on paternalistic grounds since the child undeniably has more vulnerabilities than the adult. The second-between Western and non-Western countries-mostly surfaces in the imposition of a universal (and Western) notion of childhood, both in legal international documents, such as the UNCRC and on the ground (see Khan 2010). The implications of these two relationships for this research is that, when dealing with COTM, paternalism may assume a double role in connecting the Western adult (such as an organisation advocating for the rights of the child on the move) with the non-Western child (the child on the move itself).

\section{Methods}

\section{Power, paternalism and humanitarianism}

Throughout the years, writers have tried to define power in such a way as to encapsulate all of its instances. The multi-faceted nature of power however makes this impossible without taking into account its different dimensions. Barnett and Duvall (2005) set out to do just that and ended up with a taxonomy of power that presents four faces of power.

Barnett and Duvall depart from a clear identification of the dimensions that generate different conceptualisations of power; they therefore define power as the production, in and through social relations, of effects that shape the capacities of actors to determine their circumstances and fate' (Barnett and Duvall 2005, p. 42). This definition has two critical dimensions at its core: the kinds of social relations through which power works and the specificity of social relations through which effects on actors' capacities are produced-thus the taxonomy of power shown in Fig. 1.

Barnett and Duvall's productive power concerns the production of subjects through diffuse social relations and is key to this research; it is essentially based on Michel Foucault's conceptualisation of power (Foucault
1977). It can be exemplified by the way the Other is defined, from which follows an examination of what the possible implications of those definitions are. A question immediately arises on the extent to which productive power influences the production of subjects. The answer is bound to impact on the distinction that can be made between autonomy and agency (see Bevir 1999). Productive power may have the ability to shape the quality of our interests (therefore autonomy) or it may be able to generate our capacity to have them (agency). Digeser looks back to Foucault for an answer and concludes that, since a degree of autonomy 'presupposes certain capacities that already individualize us, it is more likely that Foucault is making the deeper claim that the forging of subjects refers to the enabling or disabling of agency' (Digeser 1992, p. 980).

Since in this conceptualisation of power there are no preconceived subjects, there is therefore no agency (the capacity to have interests). The lack of real or objective interests naturally negates the necessity of a link between intentionality and power. Productive power, therefore, is not exercised through a conscious choice of a subject but unintentionally exercised by acting upon specific intentions. It permeates society and exists between each and every point of the social body.

The special relationship between power and knowledge is arguably one of Foucault's most well-known ideas. This relationship does not equate knowledge with power and in fact is made up of two hemispheres. On the one hand, no power relation exists without a field of knowledge; on the other hand, knowledge presupposes the existence of power relations. This paradox can only be unravelled by examining both sides of the relationship (Keenan 1987).

Productive power is exercised through the production of subjects. It lies in the day-to-day practices and the acceptance of a given system of beliefs (at any given point in history) as "true", thus creating systems of knowledge. This means then that systems of knowledge are a blueprint for the formation of subjects; as Digeser (1992, p. 987) put it, 'the forging of subjects requires some truth to live up to'.

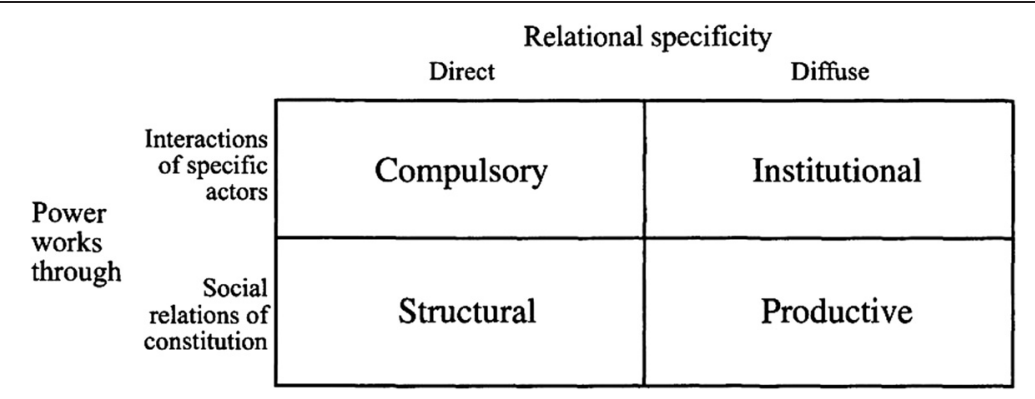

Fig. 1 A taxonomy of power (Barnett and Duvall 2005, p. 48) 
The presence of power in the production of knowledge is an easier concept to accept. After all, in century after century, coercion has been the best tool to force B to accept A's truths. Productive power claims that no truth escapes the influence of power: all knowledge is the effect of power. Foucault therefore moves away from the century-old quest for truth. In his version of power, truths are not asserted through conflicts of interest but by forging subjects and their desires so as to make them actors of productive power. This is a game-changer, since it forces any scholar to, at the very least, look upon any claim on truth (such as a universally true notion of childhood) with suspicion.

Critical discourse analysis (CDA) aims at analysing the 'opaque as well as transparent structural relationships of dominance, discrimination, power and control as manifested in language' (Wodak 1995, p. 448). In fact, it stems from 'a critical theory of language which sees the use of language as a form of social practice' (Janks 1997, p. 329). CDA is deemed to have first emerged in European discourse studies with Fairclough's Language and Power (1989) where he analysed political discourses in Britain through an innovative method that came to be known as CDA. During the past two decades, various forms of CDA have been used in multiple disciplines, including the construction of asylum-seeking subjects (see Goodman 2007, 2010) and of local perceptions in developing countries (Kalyango 2011).

The marriage between the Foucauldian method of exposing the mechanisms of power and CDA is defined in FDA. Powers (2007, pp. 26-27) claims that 'discourse analysis receives its impetus to describe power relations from Foucault's description'. This description 'provides evidence for a shift in the conceptualisation of power'. Ian Parker suggests that 'any approach which pretends to be Foucauldian is also necessarily historical, to do with the time of phenomena, how they have come into being, how they maintain themselves, and what forces may eventually lead to them disintegrating and disappearing altogether' (Parker 2013, p. 231). Today, the historical malleability of expert definitions is well-embedded in academic thought as well as the rejection of 'universal subjects, meanings, structures, realities, processes' (Allen 1986 in Powers 2007, p. 25). Moreover, the Foucauldian aspect of FDA requires an analysis of the micro-politics of power and its productive features, especially in the production of subjects (Arribas-Ayllon and Walkerdine 2008). In line with this, this research uses FDA to trace the construction in time of "children on the move" as a term, as well as the production of subjects in this field.

Barnett (2010) made the connection between productive power, paternalism and humanitarianism. He highlighted two main features of productive power that are crucial to humanitarian action. Firstly, productive power defines what is considered as a problem; it shapes reality and provides areas of intervention where actors are obliged to act in order to fix the problem-for instance, the need to protect COTM.

Intertwined with the first, the second feature of productive power is that it signals the importance of authority. Authority is similar, but not identical, to power. Of the four main types of authority described by Barnett, he thinks of moral and expert authority as the most influential in humanitarian action. Actors, like NGOs and international institutions, covet authority because it allows them to define reality-or, in other words, what counts as a problem. Authority gives actors the productive power that is classification, conceptualisation and categorisation-the key links between discourse, knowledge and power (Ibid., pp. 110-111). Reinforcing these two features of productive power is the fact that it also describes thow discursive processes and practices produce social identities and capacities as they give meaning to them' (Ibid.). Since subjects are not just the effects but also the vehicles of power, the production of knowledge has a direct impact on both the formation of subjects and the forging of their interests and self-perceptions.

The history of humanitarianism is mired with action justified by moral or expert authority (see Barnett 2011). Moral authority is bestowed on humanitarian actors because they uphold certain values that are considered as morally commendable in that particular period of time. The claim for moral authority is made by humanitarian actors on the basis that they are 'witnesses of suffering' and that the sufferers are not able to act in their own interests (Barnett 2010, p. 112).

Humanitarianism is also justified on the grounds of expert authority. This notion has gained ground as humanitarian action in general has started to become more and more professionalised, with more research and knowledge produced over the last decade. Humanitarian actors also claim knowledge from decades of organisational experience in the sector, while still preserving the ethics of impartial care that keep moral authority on its feet.

The discourse of humanitarianism therefore contains the ingredients for both emancipation and domination, and that are best explained by the notion of paternalism. The first connecting feature is that humanitarianism can be an act of imposition. There are times when the consent of the recipient is implied by their helpless situation. Yet humanitarian actors often find themselves walking on a tightrope, especially as they run the danger of giving aid where aid is not asked for. This is tightly linked to the notion of autonomy that is at the core of human dignity. The ethics of care, in this sense, can quickly come to be seen as the ethics of control (Ibid.).

A second, more overt, link that connects paternalism with humanitarianism is the urge to promote and 
safeguard the best interests of the suffering. This is the ultimate bastion for paternalism since it can be claimed that 'the welfare of another will improve relative to a decision made without that interference' (Ibid., p. 115). However, it also implies that the subject is incapable of realising and acting upon their best interests but that the humanitarian actor has the moral and expert authority to do so. Such feelings are amplified when the subject is the vulnerable child whose interests need to be protected by the humanitarian adult. The following analysis parallels that of Barnett and applies his formulation on the DU.

\section{Results and discussion}

\section{Construction of meaning}

The term 'children on the move' is not a new one. Its meaning, however, has changed over decades, and only in recent years has it become wholly associated with migrant children of all categories. Early usage of the term 'children on the move' comes across as more of a rhetorical attempt at presenting elegant niceties rather than one aimed at defining and establishing a specific term. Dottridge claims that the term began to be used around 2005 'to refer generically to children who had left their habitual place of residence to move either within their own country or to another country' (Dottridge 2012, p. 21). From then on, definitions started to emerge from different organisations, all of them focussing on child migration. By 2008, Save the Children had already begun using 'children on the move' as a term widely referring to migrant children (Reale 2008). As with most other sectors, however, defining terms in this field is not an easy task. Echoing the reflections made earlier in this research about the malleability of the concept of childhood, Delaney concedes that the field is dominated by specialist words and concepts that 'can mean different things in different places (within countries or even within organisations) or their meaning is not always clear' (Delaney 2012, p. 4).

In 2010, several international intergovernmental and non-governmental organisations met for the International Conference on Protecting and Supporting Children on the Move, organised by the Global Movement for Children in Barcelona ${ }^{5}$. This resulted in a specific working group on COTM and a subsequent publication by the International Organisation for Migration. The latter envisioned the idea of COTM to be 'a broad concept, encompassing children from diverse backgrounds and with different experiences' (Crépeau and Dottridge 2013, p. 7).

Several definitions of "children on the move" were developed, both within and outside the DU, yet the NGO under study here, Terre des Hommes, adopted its own definition in 2012 (Dottridge 2012, p. 22) referring to:

Those children who have left their place of habitual residence and are either on the way towards a new destination, or have already reached such a destination. A child [on the move] can move across State borders, or within the country. $\mathrm{S} /$ he can be on the move alone, or in a group with family members, other adults and/or children, known or unknown previously to the child. Moreover, a distinction can be made among the various children on the move, based on the reasons behind such movement. The four categories concerned are:

- Internally displaced persons

- Asylum seekers and refugees

- Migrants (i.e., for economic reasons or due to climate change, both internally and across borders)

- Trafficked persons

It is therefore evident that in the space of a few years, the term COTM became quite well-established in humanitarian discourse. It was mainly developed by NGOs out of a need to capture a wide array of categories of children under one umbrella definition, but it was also quickly adopted in the discourse of international intergovernmental organisations. In the DU, this definition includes 'categories such as the migrant children, trafficked children, street children, stateless children, refugee children, and internally displaced children' (Ensuring Protection for Children On The Move 2010).

The efforts to categorise COTM while placing them under one conceptual heading bears striking parallelisms with the totalising and individualising features of productive power. Productive power is characteristically totalising because it pervades all aspects of life and draws everything to an acceptable norm, while also being individualising in the sense that it defines individuals in relation to that norm. COTM as an umbrella term for categorised children is therefore totalising because it greatly expands the productive power of the sector beyond exploitation and human trafficking, yet it is also individualising since it calcifies the segmentation of children into predetermined categories and bases their right to be protected solely on their individual best interests, 'independently of their migration status, gender, age, health, nationality, religious or cultural belongings or any other ground' (Terre des Hommes International Federation 2012).

Thus, by introducing an umbrella term in the form of "children on the move", the discipline of protecting children embraced a large number of previously unconnected categories under one concept. All of these efforts to define and research COTM resulted in shaping reality in such a way as to create new problems and opportunities for intervention. In fact, the texts that were analysed in this research which were part of the DU carry on with their definition of COTM to identify what the issues to tackle are and in which areas the organisations can intervene. They also actively prioritise problems and, for instance, ask: 'What risks 
attached to moving should be a priority to tackle?' (Dottridge 2012, p. 56).

The authors of such texts deliberately ask where the main problems are and where and in what way the campaign may potentially intervene. These texts point towards opportunities to protect and opportunities for protection. This, however, raises another important question in the light of paternalism in humanitarianism: an opportunity for whom? Is this an opportunity for children to seek protection or for other actors to intervene and protect children? While there is a fine line between the two, the available texts seem to increasingly point to the latter case. This view is emphasised by the fact that a child protection agency is defined in the DU handbook as 'any organization that has the mandate to protect children' (Delaney 2012, p. 5, emphasis added).

The texts analysed for the purpose of this research all draw strength and legitimacy from international law and conventions. In this sense, the campaign uses the universal notion of childhood present at an international level and presents it as the "real" interest as opposed to other "perceived" interests the actors involved might have. It is here that a pertinent degree of paternalism is also revealed when the issue is analysed through the framework of productive power, where interests (real or perceived) are forged rather than predetermined. By drawing on international law, literature on COTM unwittingly imposes an "ideal" that may not be consistent with local perceptions and might be seen as being colonialist in nature.

\section{The power of authority}

A question here has to be asked: by what authority does the DU impose a specific idea of "childhood"? Humanitarians wield moral authority derived from a supposed sense of disinterested care and the authority, to speak on behalf of the victims. They consider themselves as able representatives of distant strangers because they were witnesses of suffering who have recorded the pain of the victims and can 'speak with the authority of the eyewitness' (Barnett 2010, p. 112). From the cases of moral authority derived from experience present in the texts analysed within the DU, one instance stands out for its clear reference to witness authority:

While the governments of industrialised countries appear convinced that the best response to unwanted migrant children is to send them back to where they came from, NGOs which have substantial experience of caring for such children, both as migrants in Europe and after they arrive back in their countries of origin, have very different views. (Dottridge 2008, p. 42)

By evoking the involvement of NGOs with migrant children, Dottridge highlights their moral authority and contrasts it to the views of governments. Thus, "being there" allows NGOs to speak on the children's behalf, and this authority to represent the suffering stranger gives humanitarians the subtle, productive power to influence politics, while at the same time staying out of its confines.

Similarly, expert authority is another type of authority that bears traces of productive power. The literature on COTM is characterised by appeals for more research and information to be published. Cazenave, for instance, laments the fact that the phenomenon where 'the protection of children in an area where the freedom to movement is a right but where a cross-border element hampers protection processes' is one that 'has received too little attention to date' (Cazenave 2012, p. 5); the research by Terre des Hommes is aimed at tackling this problem.

The right of organisations such as TDHIF to conduct and publish research on COTM is based on their expert authority. Like moral authority, expert authority is derived both from the experience of such organisations, and their presence on the ground. This can be noticed in excerpts such as one from (Re)Building the Future that is described by Delaney as a handbook that was developed out of literature, workshops, and consultant expertise. Research contributes to an ever-growing body of "expert" knowledge on COTM. This knowledge is generated by research units in NGOs, as well as in conferences (such as the International Conference on Protecting and Supporting Children on the Move) and working groups (such as the Inter-Agency Working Group on Children on the Move) (Crépeau and Dottridge 2013, p. 7).

Within the conceptual framework of productive power, a body of knowledge is a blueprint for the formation of subjects. A system of knowledge consists of a set of beliefs that are considered as "true" - a truth to live up to (Digeser 1992, p. 987). The establishment of a new concept of COTM, as well as the research supporting it, creates a system of knowledge that is therefore also a mechanism of power. The other side of the coin is that this generation of knowledge is also infused with productive power. This power both sustains and is sustained by the expert authority it generates.

Generating research, however, is not just an exercise to produce knowledge on COTM but it also allows for that knowledge to be used as a tool when doing advocacy work. This is one of the key objectives of the DU which aims to bring COTM to the attention of supranational (Parata 2014), regional and national institutions (AMWCY et al. n.d.). This is a way to combat 'evidence that the governments of numerous countries around the world-both developing and industrialized ones-act as if COTM were invisible' (Crépeau and Dottridge 2013, p. 8) and to campaign so as to put COTM on the political agenda by solidifying the relationship between knowledge and power. 
During his interview, Salvatore Parata emphasised the fact that one of the main reasons for the DU to conduct research is to generate expertise for the campaign. This research is seen as a key tool for raising awareness among legislators and decision-makers and engaging in advocacy that is backed with the necessary expertise.

Literature on COTM, and the DU in particular, also emphasises the need to gather as much data as possible on COTM so as to be able to act knowledgeably. States are therefore encouraged to 'strengthen their data-collecting and -analysing capacity regarding migrant children in all phases of the migratory process, in order to formulate and implement child-sensitive migration policies' (Ibid., p. 2).

Furthermore, most texts indicate that the best agents to gather information are the children themselves. Here, one can observe a key effect of productive power in the generation of knowledge since, by transforming children into agents who act upon the principles of the rights of COTM, this body of knowledge is forging children into new subjects. The children's interests (real or perceived) are not trampled but forged through productive power. In this way, acting on the knowledge on COTM inevitably promotes the interests of the child, which were given birth by the same productive power.

Subjects, however, are produced not only from children but also from the aid workers themselves. Part of the publications in the DU is aimed at training workers in the field of child protection to enable them to act on the needs of COTM. Many of the texts analysed within the case study of the campaign, in fact, had this purpose in mind. The two key publications in this regard were those by Dottridge and Delaney. Delaney clearly states this by declaring that the 'primary purpose of this handbook is to expand on project workers' understanding of how to help trafficked children' (Delaney 2012, p. 7). This authority to provide training and publish handbooks on COTM (and thereby develop a body of knowledge that is used in turn to produce subjects) seems to be derived from experience and expertise. The handbook What can you do to protect Children on the Move? gives an overview of how it was developed and brings to attention the expertise of the consultant, the experience of the people participating in the workshops, as well as the difficulty to clearly define children on the move (Dottridge 2012, p. 13).

One of the most important features of productive power is the semblance of scientific objectivity that is given to knowledge. Knowledge that is scientific is rarely disputed since it claims to be apolitical and objective (Digeser 1992). The discourse on COTM aspires to this position. Two passages stand out from the publications under study:

There is much debate about the use of the word "victim" to describe children who may have been trafficked; many people think this label can trap children in a situation of powerlessness. Thus, the term survivor is preferred by many people working with children. However, both terms are problematic because they define and make judgements about children. In this handbook, we use the terms trafficked children, children who have been trafficked or former trafficked children because they are purely descriptive or what has happened to children. Delaney 2012, p. 6, emphasis added)

Furthermore, it [the notion of mobility] is a neutral term, without positive or negative connotations. It can then be used in an objective manner, without introducing at the outset ideological or normative connotations that might distort the look and the analysis. (AMWCY et al. n.d., p. 10-11, emphasis added)

This form of productive power is totalising because it draws on scientific objectivity to normalise subjects through constant measurement and observation. Expert authority, however, is the foundation for techniques of measurement and observation (see Panopticism in Foucault 1977). This relies on a universal (and scientifically objective) concept for COTM and ways to gather information on them. Moreover, the texts analysed call for the techniques of surveillance to be legally, and geographically, expanded through systems of protection. It is important to note that the second extract quoted above comes from a child-run organisation of working children (commonly referred as NATs-Niños y Adolescentes Trabajadores). Cordero Arce makes the compelling argument that these organisations are an example of how an emancipatory discourse of children's rights can emerge, yet he fails to convincingly show how this discourse could be institutionalised and indeed reveals several mechanisms through which the human rights regime actively resists it (Cordero Arce 2012). Crucially, this shows how an organisation such as the AMWCY has been integrated into, and (re)formed in accordance to, the ideas of the DU.

The literature on the disappearance of children from institutions in Europe is interesting to look at with regard to systems of protection. The publication on the surfeit of children in Europe mainly focuses on the problem represented by the fact that

the principle of actively searching for a minor who has disappeared from an institution is very rarely implemented, in contrast to the immediate search which is initiated when a national child disappears. (Terre des Hommes 2009, p. 11)

An escape of a child from the radar of state institutions, even of its own free will, is deemed to be unacceptable. The report conveys the message that, in the 
best interest of the child, it needs to be under the protection of the state, and that the latter should do everything in its power to ensure that the minor is always under surveillance.

Thus, expert authority is always at the centre of the discourse on COTM. Expert authority is multi-faceted and is a key reflection of productive power: its use in advocacy work can be explained through the special relationship between knowledge and power; its enabling, through the use of children, the gathering of information and the training of workers, thus forges docile subjects; and the necessity to spread its use legally and spatially is a panoptical exercise in the name of the best interest of the child.

\section{Paternalism-imposition in the name of best interests?}

One of the main ways for human rights organisations to deflect accusations of paternalism is to point out the right to participation ${ }^{6}$. The will to make participation happen seems true and sincere. Yet there still seems to be an acknowledged gap 'between the views expressed and the decisions the NGO [makes] that [affect] the child' and that 'on the whole it remains true that [the children] are either given no opportunity to express their views or, if they are, their views are ignored' (Dottridge 2012, p. 62). To protect COTM, there also needs to be a person who facilitates the process and knows where it is headed. In fact, demand 9 suggests that although NGO's and other actors are obliged to listen to children, they still have the role of 'designing and implementing projects for them' (Terre des Hommes International Federation 2012, p. 3).

The impression that the concept of participation is only paid lip-service is augmented by the incessant reminders in the texts that, 'while the participation of children is important, it is critical to recognize that the responsibility of protecting children remains with adults' (Delaney 2012, p. 30 ) and that 'we must always be clear that adults are responsible for protecting children' (Ibid., p. 24). This is another aspect of the rights of COTM that suggests, and indeed, justifies paternalism. COTM are treated first and foremost 'according to child protection legal standards and not exclusively according to an illegal immigration perspective' (Terre des Hommes 2009, p. 12). They are therefore 'treated as children first' (Crépeau and Dottridge 2013, p. 7). Moreover, the nature of the "child" is typically represented as that of a vulnerable being in need of protection. This Western perspective of the child is based on the UNCRC in that, while it

recognizes, on the one hand, that children are holders of rights and capable actors in their own respect, it also sees childhood as a phase in which the girl or boy is still evolving physically, mentally and emotionally, thus requiring special measures to protect and promote their development (Lansdown, 2005). (Thatun and Heissler in Crépeau and Dottridge 2013, p. 99)

The difference between this view of childhood and the notion of participation is surprisingly evident. Delaney mentions that one should be careful not to mistake "pseudo-maturity" in children with actual maturity, explaining that pseudo-maturity is

appearing to be more mature than is developmentally appropriate [...] resulting when children learn that they need to take care or themselves and when adults are not considered a source of support and protection.

(Delaney 2012: 9)

Perpetuating a universal idea of childhood should be seen as being inherently problematic, especially since it adds another layer of paternalism to the more obvious adult-child dynamic, this time in the form of cultural colonialism. Crépeau and Dottridge (2013, p. 4) state that 'we should always devise a treatment for migrant children that we would consider appropriate for 'our' own children', in a context where "our" refers to us as NGOs with universal (or Western) principles. This may be translated into a form of paternalism based on expert authority that is drawn from a specific system of knowledge on COTM that creates two subjects: the developed adult and the developing COTM.

The most important bulwark for the interference of humanitarians in the life of the COTM is the idea that doing so is in their best interests. The "best interests of the child" (enshrined in Article 3 of the UNCRC) is defined as the concept of ensuring that what actions take place or what plans are made places the most importance on the needs of a child and their welfare' (Delaney 2012, p. 4). Identifying the 'needs' in this case is an exercise that relies on moral and expert authority and also on the ability to gather information from the participating child. Participation thus becomes a tool to construct the child's best interests according to international norms and justify acting upon them. It is important, for instance, to find out 'about children's experiences and to make decisions with them and on their behalf, which explicitly make the best interests of the child concerned a primary consideration in the decision' (Crépeau and Dottridge 2013, p. 9, emphasis added).

Workers are obliged 'to make the best interests of the child a primary consideration in all actions that concern either an individual child or a group of children' (Dottridge 2012, p. 44) and observe that 'other primary considerations (such as a Government's policies on immigration) may not be given more importance that (sic) a child's best interests in decisions and actions affecting that child' (Ibid., p. 5). Thus, principles based on international norms trump local views yet again. 


\section{Conclusions}

In this paper, I looked at two main features of productive power in the field of the rights of COTM, as represented by the DU. The first was the ability to shape reality. In order to look for this characteristic, I sought to trace the development of the concept of COTM and how establishing this concept allowed the actors involved to create new areas of intervention. I also explored how the legitimacy of this process stems from paternalistic cultural colonialism in the form of international legislation based on Western values. Secondly, the productive power in the field was revealed through the reliance on moral and expert authority. Indeed, a Foucauldian discourse analysis of both the publications and interview from the case study revealed that the generation of knowledge through research is one of the main aims of the campaign. Expert authority is also fundamental in the use of knowledge on COTM to forge subjects in its own image, thus giving strength to the Foucauldian dynamic between power and knowledge. This dynamic is also strengthened by the call for more surveillance on COTM through international systems of protection, which reflects the disciplinary aspect of productive power.

Productive power in the field of COTM can be explained through the notion of paternalism. The simplest way to define paternalism is as an imposition in the name of a particular set of best interests. The DU, in line with other efforts aimed at the protection of child rights, invokes two important principles in this regard. The first is that of participation. One of the main objectives of the campaign is to promote the child's right to be heard, yet, paradoxically, it also asserts the position of the adult as the better-placed decision-maker in the adult-child relationship. This leads to the principle of best interests, where the act of imposition is justified by declaring that it is in the best interests of the child. This is one of the most important principles of child rights and further reinforces cultural colonialism by safeguarding "real" (Western) interests at the expense of "perceived" interests, once it has been established that both real and perceived interests do not escape the net of productive power.

It can therefore be concluded that, like the rest of humanitarianism, the field of campaigning for the rights of COTM, is inherently paternalistic. It is based on a body of knowledge constructed over the course of this century and sustained by moral and expert authority, and it uses these to justify the act of imposition of Western-based principles in the name of the best interests of the child. However, the purpose of this research was not to provide a value-laden judgement on the case study. Within the Foucauldian conceptual framework informing this analysis, no truth escapes power (Taylor 1984). It is therefore not in the interest of this study to judge whether the paternalistic nature of the rights of COTM should be condemned or exalted. Its conclusions, however, cannot but lead us to embark on a process of dispelling the myth of a humanitarianism based solely in the world of ethics. Ethics, in the light of this research, are both powerful and subjective.

Rather than censured, the view that modern humanitarianism is paternalistic should be acknowledged and given serious thought. It is paternalism which best explains the tensions with which the international humanitarian order constantly grapples and, in an age where humanitarianism is becoming more and more professionalised (and thus heavily reliant on expert authority), it cannot be ignored. We need to be aware that knowledge and power are intrinsically linked and that this, as shown by this research, may lead to even more paternalism rather than less.

A number of pertinent questions remain, but two main concerns need to be underlined. First of all, if the nature of humanitarianism is paternalistic, can paternalism be justified? Can the humanitarian be trusted to design the justifiable limits of paternalistic intervention? And, more importantly, can there be a humanitarianism which is not paternalistic? Secondly, and relatedly, it can be observed that a paternalistic humanitarianism may lead to a "schizophrenic" situation; it leads us, as humanitarians, to either act in bad faith (and deny the fact that we are being paternalistic in our work) or to become disenchanted with the sector and abandon the humanitarian project. These concerns represent a conceptual cul-de-sac that can only be escaped through more thought and research. Crucially, this dead end leads us to question the conceptual sustainability of the current international liberal humanitarian order and encourages us to put more thought in critical research outside its confines.

\section{Endnotes}

${ }^{1}$ While the construction of the definition of "children on the move" will be explored in this research, this dissertation will adopt one of the main definitions of the Destination Unknown campaign as a working definition: 'Children who move for more than a few days at a time, within or between countries, for a variety of reasons, voluntarily or involuntarily, with or without their parents or other primary caregivers.' (Dottridge 2012, p. 23)

${ }^{2}$ Including writers such as the following: Archard, Status of Children; Khan, Discourses On Childhood; Dekker et al., Childhood In History; Frijhoff, Discovery of Childhood (Dekker et. al 2012).

${ }^{3}$ For example, Hofstetter's writings on how important science was in transforming the child into a schoolchild. Hofstetter, L'Enfant En Écolier (Hofstetter 2012).

${ }^{4}$ For a further exploration of the paternalistic approach to child labour, see Liebel 2013 


\author{
${ }^{5}$ One notes that it is called the Global Movement \\ for, not of, Children. \\ ${ }^{6}$ In Hanson and Nieuwenhuys, Reconceptualising \\ Children's Rights, participation is explored through three \\ interrelated concepts (livings rights, living history and \\ translation) and it is emphasised that children's rights \\ need to be contextualised rather than universal. Also \\ see Pupavac, Misanthropy without Borders (Hanson \& \\ Nieuwenhuys 2013).
}

\section{Abbreviations}

CDA: critical discourse analysis; COTM: children on the move; DU: Destination Unknown campaign; FDA: Foucauldian discourse analysis; NGO: nongovernmental organisation; TDHIF: Terre des Hommes International Foundation; UN: United Nations; UNCRC: The United Nations Convention on the Rights of the Child

\section{Competing interests}

The author declares that he has no competing interests.

\section{Acknowledgements}

I would like to express my sincere gratitude to my supervisor at the University of Malta, Dr. Maria Pisani, for, without her supervision and constructive criticism, the completion of this research would not have been possible.

The questions behind this research were seeded during my internship with Terre des Hommes International Foundation, whose staff I must thank for their help both during the internship itself and also while collecting data for this study. Among these, I would like to specifically mention Eylah Kadjar, who tutored me during my stay in Geneva, and Salvatore Parata, who provided crucial information about the Destination Unknown campaign. Alongside these, I would also like to thank William Grech and Dominik Kalweit at KOPIN, which is the Destination Unknown partner in Malta, for their support in the collection of data.

Received: 25 October 2015 Accepted: 6 January 2016 Published online: 01 March 2016

\section{References}

AMWCY, Terre Des Hommes Foundation, ENDA Jeunesse Action, ILO, PLAN WARO, IOM, Aide À L'Enfance - Suède and UNICEF WCARO. (n.d.) Which protection for children involved in mobility in West Africa. [pdf] Available at: http://destination-unknown.org/wp-content/uploads/201201_tdh_projet_ mobilit en.pdf Accessed: 3 Mar 2014

Archard D (2006) The moral and political status of children. Public Policy Res 13(1):6-12

Arribas-Ayllon M, Walkerdine $V$ (2008) Foucauldian discourse analysis, 1st edn, The SAGE handbook of qualitative research in psychology. London, SAGE Publications

Barnett M (2010) Humanitarianism, paternalism, and the UNHCR, Refugees in International Relations., p 105

Barnett M (2011) Empire of humanity. Cornell University Press, Ithaca

Barnett M, Duvall R (2005) Power in international politics. Int Organ 59(1):39-75

Bevir M (1999) Foucault and critique: deploying agency against autonomy. Political Theory 27(1):65-84

Burman E (2008) Developments. Routledge, London

Cannella G, Viruru R (2004) Childhood and postcolonization. RoutledgeFalmer, New York

Cazenave, P. (2012) Protecting migrant children in a freedom of movement area. [e-book] Terre des hommes. Available at: http://destination-unknown.org/ wp-content/uploads/1554_Tdh_english_improved_original.pdf Accessed: 1 Feb 2014

Cordero Arce M (2012) Towards an emancipatory discourse of children's rights

Crépeau F, Dottridge M (2013) Children on the move. International Organization for Migration (IOM), Geneva

Dekker J, Kruithof B, Simon F, Vanobbergen B (2012) Discoveries of childhood in history: an introduction. Paedagogica Historica 48(1):1-9

Delaney, S. (2012) (Re)building the future. [e-book] Terre Des Hommes International Federation. Available through: Destination-Unknown.org via
http://destination-unknown.org/wp-content/uploads/Handbook-ReBuildingthe-Future-WEB.pdf Accessed: 21 Jan 2014

Destination Unknown. (2014) Destination Unknown campaign-to protect children on the move. [online] Available at: http://destination-unknown.org Accessed 23 Oct. 2013.

Digeser P (1992) The fourth face of power. J Polit 54(4):977-1007

Dottridge M (2008) Kids abroad. Terre des Hommes International Federation, Geneva

Dottridge M (2012) What can you do to protect children on the move, Destination Unknown Campaign. Terre des Hommes International Federation, Geneva

Ebrahim H (2012) Tensions in incorporating global childhood with early childhood programs: the case of South Africa. Australasian J Early Childhood 37(3):80-86

Ensuring protection for children on the move. (2010) [pdf] Bangkok: Southeast Asia conference on children on the move. Available through: DestinationUnknown.org via http://destination-unknown.org/wp-content/uploads/ away-from-home-booklet-FINAL-for-web.pdf Accessed: 19 Jan 2014.

Fairclough N (1989) Language and power. Longman, London

Fass P (2013) The Routledge history of childhood in the western world. Routledge, London

Finn J, Nybell L, Shook J (2010) The meaning and making of childhood in the era of globalization: challenges for social work. Child Youth Serv Rev 32(2):246-254

Foucault M (1977) Discipline and punish. Pantheon Books, New York

Frijhoff W (2012) Historian's discovery of childhood. Paedagogica Historica 48(1): $11-29$

Gadda A (2008) Rights, Foucault and Power: a critical analysis of the United Nation Convention on the Rights of the Child, Edinburgh Working Papers in Sociology., p 31

Global Movement for Children. (2010) International conference on protecting and supporting children on the move. Available at http://www.gmfc.org/ images/pdf/com_executive\%20summary.pdf

Goodman S (2007) Constructing asylum seeking families. CADAAD 1(1):35-49

Goodman S (2010) It's not racist to impose limits on immigration: constructing the boundaries of racism in the asylum and immigration debate. CADAAD $4(1): 1-17$

Hamed Aladaylah M (2012) Postcolonial reading of a colonial text. English Language Teaching 5(9):122

Hanson K, Nieuwenhuys O (2013) Reconceptualizing children's rights in international development. Cambridge University Press, Cambridge

Hofstetter R (2012) La transformation de l'enfant en 'ecolier (du 19e au milieu du 20e si'ecle): les "eurekas" des sciences de l'homme naissantes, entre scientisme et romantisme: un "naturalisme" de l'enfance. Paedagog Hist 48(1):31-50

Janks H (1997) Critical discourse analysis as a research tool. Discourse: Studies Cult Pol Educ 18(3):329-342

Kalyango Y Jr (2011) Critical discourse analysis of CNN International's coverage of Africa. J Broadcasting Electronic Media 55(2):160-179

Keenan T (1987) I. The "paradox" of knowledge and power reading Foucault on a bias. Political Theory 15(1):5-37

Khan A (2010) Discourses on childhood: policy-making with regard to child labour in the context of competing cultural and economic perceptions. Hist Anthropol 21(2):101-119

Liebel M (2013) 'Do children have a right to work? Working children's movements in the struggle for social justice' in reconceptualising children's rights in international development, 1st edn. Cambridge University Press, Cambridge

Nietzsche F, Smith D (2008) On the genealogy of morals, 1st edn. Oxford University Press, Oxford

Parata, S. (2014) Interview on the Destination Unknown campaign strategy. Interviewed by Kyle Vella [Skype] 22 April 2014

Parker I (2013) Discourse analysis: dimensions of critique in psychology. Qual Res Psychol 10(3):223-239

Powers P (2007) The philosophical foundations of Foucaultian discourse analysis. CADAAD 1(2):18-34

Pupavac V (2001) Misanthropy without borders: the international children's rights regime. Disasters 25(2):95-112

Reale, D. (2008) Away from home-protecting and supporting children on the move. [e-book] Save the Children UK. http://www.savethechildren.org.uk/ sites/default/files/docs/Away from_Home_LR_1.pdf Accessed: 24 Jan 2014

Reynolds P, Nieuwenhuys O, Hanson K (2006) Refractions of children's rights in development practice: a view from anthropology-introduction. Childhood 13(3):291-302 
Taylor C (1984) Foucault on freedom and truth. Political Theory 12(2):152-183

Terre des Hommes (2009) Disappearing, departing, running away—a surfeit of children in Europe. Staempfli Publications, Bern

Terre des Hommes International Federation (2012) Destination Unknown 10 demands, Destination Unknown Campaign. Terre des Hommes International Federation, Geneva

Unworldyouthreport.org, (2013). UN World Youth Report. [online] Available at: http://www.unworldyouthreport.org/index.php Accessed 7 Jun. 2014.

Wodak, R. (1995). Critical Linguistics and Critical Discourse Analysis. Language and Ideology. Antwerp: International Pragmatics Association.

\section{Submit your manuscript to a SpringerOpen ${ }^{\circ}$ journal and benefit from:}

- Convenient online submission

- Rigorous peer review

- Immediate publication on acceptance

- Open access: articles freely available online

- High visibility within the field

- Retaining the copyright to your article

Submit your next manuscript at $>$ springeropen.com 